\title{
Editorial
}

\section{Market and regulatory balance}

Journal of Banking Regulation (2012) 13, 1-3. doi:10.1057/jbr.2011.24

All of the official reviews and reports following the financial crisis in 2008-2009 have led to a new era of substantial re-regulation in most countries with the rejection of the earlier dominant ideas of market efficiency and rational expectations, as well as a consequent natural market correction and self-regulation. It is not that these theories were fundamentally wrong in all respects but simply that they were relied on to an excessive, and arguably wholly irresponsible, degree both by markets and the authorities and allowed to divert attention from necessary but balanced and proportionate financial regulation and supervisory compliance. The danger now is that we have moved too far to the other extreme with re-regulation stifling the necessary services and support that we need from the financial sector which will constrain both short-term recovery and future longer-term growth and prosperity.

The reconstituted Financial Stability Board (FSB), formerly the Financial Stability Forum, has produced a formidable number of new technical and policy papers. It has also forced other sector technical committees to undertake a fundamental review of their earlier standards and principles and report back through an almost endless series of continuing progress reports. The Basel Committee on Banking Supervision has issued over 30 papers (possibly nearer 40 now) in response to the crisis with its work principally focusing on enhanced capital, liquidity and leverage under Basel III and additional new principles on risk management, corporate governance, remuneration, supervisory college supervision and crossborder bank resolution. This is an impressive and balanced package in a difficult area. The EU has more belatedly announced over 47 separate initiatives having grasped the opportunity for further reform left open through an almost endless period of 'bank bashing' and bank blame and recrimination within Europe and elsewhere. The EU's latest initiative may nevertheless only have the effect of forcing large areas of financial activity outside Europe though an ill-judged and inevitably regressive and unsuccessful financial transaction tax (FTT). This is in addition to other restrictions on bank remuneration (bonus) packages and national bonus taxes and bank levies already imposed at the national levels.

The UK Coalition Government has separately pushed forward its politically driven new structural agenda with the abolition of the Financial Services Authority (FSA) and re-transfer of core supervisory function to the Bank of England through its new Prudential Regulatory Authority (PRA) subsidiary and allocation of non-prudential matters to a new Financial Conduct Authority (FCA). The most significant demonstration of the new more onerous control culture that has emerged was with the enactment in the United States of the 2319 page Dodd Frank Wall Street and Consumer Protection Act in July 2010 with volumes of new rules and institutional and substantive regulatory changes to follow. Dodd Frank specifically includes a partial reintroduction of Glass Steagall investment and commercial banking separation under the 'Volcker' restrictions on proprietary (prop desk) trading. The United Kingdom is now expected to adopt a less extreme, but still costly, form of 
retail ring-fencing, or 'subsidiarisation', of function within larger groups following the final Independent Banking Commission's (ICB) report in September 2011.

Financial markets will now have to operate within considerably heavier regulatory and financial cost constraints. While almost all aspects of this new regulatory programme are claimed to be financial stability directed, much of this has been driven by separate media, political or other federal agenda. This will inevitably result in a substantial restructuring of the financial sector and the global financial system over the following decades. The natural consequence of this will be to limit financial earnings and profitability, by possibly over one-third under some estimates, which will also inevitably constrain lending and credit volumes, increase borrowing costs, raise other service fees as well as limit innovation and corporate and consumer choice and selection longer term. The smallest and largest financial groups may all be marginally safer and more stable although only at significant wider costs which will inevitably be passed back to government, corporate and household customers. The financial stability results of all of this are also uncertain as the additional core bank controls imposed will simply force funding and investment into other less wellregulated areas.

Certain changes have to be fully supported, such as the general increase in capital and liquidity levels within the larger complex financial groups, the new focus on strengthened internal risk management, governance and incentives as well as on enhanced and more effective external supervision. The earlier 'too big to fail' problem can be largely dealt with through new pre-crisis internal 'Recovery and Resolution Programmes' (RRPs or 'living wills') supplemented through post-crisis official 'Special Resolution Regimes' (SRRs) in the event that bank-designed RRPs are ineffective and fail to deal with any specific new crises. Further guidelines and procedures are still being negotiated on cross-border crisis management with additional regulatory adjustments to be imposed on all Global Systemically Important Financial Institutions (G-SIFIs) under new FSB measures.

Market oversight will be substantially strengthened through the development of new macro-prudential models, especially with the US Financial Services Oversight Council (FSOC), EU European Systemic Risk Board (ESRB) and UK Financial Policy Committee (FPC) within the Bank of England. Each of these should be able to identify and respond to emerging risks and threats to the stability of the wider financial system and real economy. Although financial stability did form part of the statutory responsibilities of most central banks, all of the new crisis management tools referred to should allow them to discharge these functions more successfully in future without the same omissions.

Central banks have also had to re-consider the need for extended lender of last resort (LLR) support mechanisms although only 'quietly' behind closed doors to avoid further moral hazard. New sets of contingency support facilities have had to be agreed to avoid the earlier difficulties that arose in having to design and set these up on an ad hoc, and unnecessarily erratic and unfortunately disruptive, basis as the last crisis unfolded. These include reserve options covering individual non-bank funding (prevented under more traditional LLR rules), general and specific market liquidity (especially in new 'shadow banking' areas), wholesale guarantees (to allow existing lending to be refinanced and rolled-over), re-capitalisation (to increase loss absorbancy and avoid bank stock price collapses) and distressed (toxic) asset purchase (on a US model) or asset insurance (on a UK model). Diplomatic discretion and an attachment to a traditional policy of 'controlled ambiguity', as well as understandable concerns with further political and public outcry, have prevented central bank staff from discussing these issues more openly.

It has to be accepted that sufficient core new supervisory and regulatory initiatives may have already been agreed or proposed. The 
underlying and proper purpose of financial regulation should always been to identify and manage risk and not to engage in endless, and irrelevant, cycles of recrimination and blame. Substantial new reform programmes have been constructed, especially in terms of strengthened internal risk management and governance, capital, liquidity and leverage cover, pre-crisis contingency restructuring and post-crisis resolution with cross-border crisis management as well as extended support in the most extreme events.

The earlier two-decade period of extended 'Financial Stability' or 'Great Moderation' was followed by an unfortunately severe, but still relatively short, lapse into 'Financial Instability' and 'Great Contraction'. This should not be allowed to unfold into a further extended period of continuous 'Financial Fragility' and 'Endless Constriction'. Earlier supervisory and regulatory failures must be dealt although these should not be transformed into a much more expensive, uncontrolled and stifling period of 'Great Regulatory Excess'.

The earlier unpredicted global recession that began in Autumn 2008, following the collapse in world stock market prices in September 2008, still haunts the world economy which stands on the edge of a possible 'Double Dip' recession, at minimum, and with the threat sovereign default, at the other extreme, including most specifically in the Eurozone area. Rather than continue to restrict and overburden the financial sector, officials must try to assist it stabilise and recover. Wider growth and recovery will only be possible with stable and productive financial institutions that can channel capital and funding and carry out their other necessary functions in terms of savings, credit and payment as well as pricing, investment and risk cover. Most of the losses suffered by these institutions arose as result of the recession and faltering recovery and did not cause the initial crisis and collapse directly. They were then to a large extent consequential rather than causal which has been unfortunately forgotten by many media and other commentators.

A certain degree of political and policy overreaction was unfortunately predictable, if not inevitable, certainly following the severity of the last crisis. Insightful and targeted reform is fully justified but without unnecessary, destructive and ultimately ineffective excessive re-regulation. The global financial crisis was a complex event with multiple causes and contributing factors having since been identified. These include lax monetary policy (and low interest policies), global trade imbalances with excessive liquidity (and a consequent 'search for yield' and higher consequent investment risk), significant credit rating risk pricing errors, weak regulatory oversight and excessive borrowing by governments, companies and households. All of these issues cannot be dealt with through overly simplistic bankbased penalties and reforms.

Politicians and regulators should now look to adopt a more positive and constructive relationship with the financial industry. The financial sector, and the inherent advantages of financial intermediation, credit and investment, must be used to re-build strength and recovery and certainly assist to do so before the next major crisis which may regrettably follow surprisingly quickly. Everything ultimately comes down to market and regulatory balance, and continued market confidence, which may have been unfortunately lost or misplaced in a prevailingly punitive and overly re-regulatory climate at this time.

GA Walker

Centre for Commercial Law Studies, London 